\title{
Demethylation and degradation of phenylmethylethers by the sulfide-methylating homoacetogenic bacterium strain TMBS 4
}

\author{
Jan-Ulrich Kreft, Bernhard Schink \\ Fakultät für Biologie, Lniversität Konstanz, Postfach 5560, W-7750 Konslanz, Germany
}

Received: 5 July 1992/Accepted: 26 October 1992

\begin{abstract}
Biochemical studies on anaerobic phenylmethylether cleavage by homoacetogenic bacteria have been hampered so far by the complexity of the reaction chain involving methyl transfer to acetyl-CoA synthase and subsequent methyl group carbonylation to acetyl-CoA. Strain TMBS 4 differs from other demethylating homoacetogenic bacteria in using sulfide as a methyl aceeptor, thereby forming methanethiol and dimethylsulfide. Growing and resting cells of strain TMBS 4 used alternatitively $\mathrm{CO}_{2}$ as a precursor of the methyl acceptor $\mathrm{CO}$ for homoacetogenic acetate formation. Demethylation was inhibited by propyl iodide and reactivated by light, indicating involvement of a corrinoid-dependent methyltransferase. Strain TMBS 4 contained ca. 750 nmol g dry mass $^{-1}$ of a corrinoid tentatively identified as 5-hydroxybenzimidazolyl cobamide. A photometric assay for measuring the demethylation activity in cell extracts was developed based on the formation of a yellow complex of $\mathrm{Ti}^{3+}$ with 5-hydroxyvanillate produced from syringate by demethylation. In cell extracts, the methyltransfer reaction from methoxylated aromatic compounds to sulfide or methanethiol depended on reductive activation by $\mathrm{Ti}^{3+}$. ATP and $\mathrm{Mg}^{2+}$ together greatly stimulated this reductive activation without being necessary for the demethylation reaction itself. The specific activity of the transmethylating enzyme system increased proportionally with protein concentration up to $3 \mathrm{mg} \mathrm{ml}^{-1}$ reaching a constant level of $20 \mathrm{nmol} \mathrm{min}^{-1} \mathrm{mg}^{-1}$ at protein concentrations $\geq 10 \mathrm{mg} \mathrm{m}^{-1}$. The specific rate of activation increased in a non-linear manner with protein concentration. Strain TMBS 4 degraded gallate, the product of sequential demethylations, to 3 acetate throngh the phloroglucinol pathway as found earlier with Pelobacter acidigallici.
\end{abstract}

Abbreviations: BV, benzyl viologen; CTAB, cetyltrimethylammonium bromide; $\mathrm{H}_{4}$ folate, tetrahydrofolate; MOPS, 3-[N-morpholinolpropanesulfonic acid; MV, methyl viologen; NTA, nitrilotriacetate; $t_{d}$, doubling time: $T M B, 3,4,5$-trimethoxybenzoate

Correspondence to: J.-U. Kreft
Key words: Methyl transfer - Demethylation - Mcthoxylated aromatic compounds - Ether cleavage Corrinoids - Homoacctogenic bacteria - Phloroglucinol pathway - Dimethylsulfide

Aerobic degradation of ether compounds is a well-known process (Axelrod 1956). Hydroxylation of a carbon atom vicinal to the ether bridge by a monooxygenasc reaction transforms the stable ether bond into a readily decomposing hemiacetal strueture (Bernhardt et al. 1970). Anaerobic cleavage of ether linkages was first demonstrated in methanogenic enrichment cultures (Healy and Young 1979), and pure cultures of homoacetogenic bacteria demethylating methoxylated aromatic compounds werc isolated later (Buche and Pfenuig 1981). Numerous other bacteria, predominantly homoacetogens, capable of anaerobic cther cleavage have since been described (Schink et al. 1992).

Studies on the biochemistry of this ether cleavage reaction with ${ }^{18} \mathrm{O}$-labcled phenylmethylethers demonstrated that the oxygen stays attached to the aromatic residue, and the cleavage is a demethylation rather than a hydrolytic demethoxylation reaction (DeWeerd et al. 1988). Experiments with cell extracts were only of limited success (Wu et al. 1988; Doré and Bryant 1990), probably due to the complexity of the methyltransfer sequence from the substrate to acetyl-CoA synthase, and subsequent carbonylation to acetate. Berman and Frazer (1992) obtained higher demethylation activities in cell extracts by using $\mathrm{H}_{4}$ folate as methyl acceptor, thus circumventing the steps of acetate synthesis.

The recently isolated strain TMBS 4 uses sulfide as methyl acceptor (Bak et al. 1992). Methylation of sulfide is a property not shared by known homoacetogenic bacteria, but widespread in scdiment ecosystems (Finster et al. 1990). In sediments, bacteria similar to strain TMBS 4 outnumber other homoacetogens, but cannot be isolated by enrichment procedures which select for faster growing organisms similar to Acetobacterium woodii (Bak et al. 1992). 
Methyltransfer from methylethers to sulfide can be expected to be an even simpler system than transfer to $\mathrm{II}_{4}$ folate, if sulfide methylation is a side reaction of the demethylating methyltransferase with sulfide, rather than being catalysed by a special methyltransferase. Hence, we began studying the demethylation reaction in cell suspensions and cell cxtracts of strain TMBS 4.

\section{Materials and methods}

\section{Media and growth conditions}

Strain TMRS 4 (DSM 6591) was kindly provided by Dr. F. Bak, Marburg. Germany. Strain TMBS 4 was grown in bicarbonatebuffered $(\mathrm{pH}$ 7.2) freshwater mincral medium prepared as previously described, under a $\mathrm{N}_{2} / \mathrm{CO}_{2}(9: 1, v / v)$ atmosphere (Widdel and Pfennig 1981). It contained 8-vitamm solution (Finster et al. 1992); trace element solution SL 10 (Widdel ct al. 1983); Nathiosulfate $(50 \mu \mathrm{M})$ as sulfur source, and Na-ascorbate or cysteme $\mathrm{HCl}(1 \mathrm{mM})$ as reducing agent. Substrates $(1-6 \mathrm{mM})$ werc added as $\mathrm{Na}$-salts to the medinm from filter-sterilized anoxic stock solutions. Cultures were incubated at $30^{\circ} \mathrm{C}$ in the dark.

Growth parameters at various substrate concentrations (1-6 mM) were determined measurung optical density $(578 \mathrm{~nm}, 1 \mathrm{~cm}$ light path cuvettes), substrate and acetate concentrations at regular time intervals. Cell dry mass was determined directly at the end of growth by filtration of the culture. In the case of gallate, the optical densitics were corrected for the gallate concentration-dependent bluish color of the medium.

\section{Preparation of cell suspensions and cell exiracts}

All steps were performed under $N_{2}$ atmosphere in rubber-sealed glass vessets $(120 \mathrm{ml}, 25 \mathrm{ml}, 8 \mathrm{ml}$, or $4 \mathrm{ml}\}$ which were kept on ice. Cultures, suspensions, or extracts were transferred between vessels using gas-tight tube connections or syringes, Cells were harvested at the late exponential growth phase by centrifugation at $2000 \times \mathrm{g}$ for $20 \mathrm{~min}$, washed once with anoxic $50 \mathrm{mM}$ potassium phosphate or MOPS $\mathrm{K}^{+}$buffer, $\mathrm{pH} 7.2$, and resuspended in the same buffer. All cell suspension experiments were performed anoxically at room temperature in aluminum-wrapped glass vials. Activities were expressed on the hasis of protein concentration. For light-treatment of cell suspensions ( $2 \mathrm{ml}$ of ecll suspension with an $O D_{578}$ of 5 in glass vials with $1.2 \mathrm{~cm}$ i.d.) light from a cold light helogen lamp $(150 \mathrm{~W})$ was used. The val was exposed to a light intensity of $1400 \mu 1100 \mathrm{~s}^{-1} \mathrm{~m}^{-2}$, measured with a L1-189 (LI-COR, Lincoln, Nebraska, USA) quantummeter with quantum sensor.

Cell exiracts were prepared by disruption at $140 \mathrm{MPa}$ in a French pressure cell ( 5 passages) gassed with $\mathrm{N}_{2}$. The crude extract was centrifuged at $4300 \times \mathrm{g}$ for $30 \mathrm{~min}$ to remove cell debris.

Ccll extracis with high protein content (ca. $30 \mathrm{mg} \mathrm{ml}^{-1}$ ) were prepared for methyltransfer assays by a modified procedure: $10 \mathrm{l}$ of culture werc harvested in a centrifuge equipped with a continuous flow rotor gassed with $\mathrm{N}_{2}$ and rinsed with anoxic $\mathrm{Ti}^{3+}$-reduced buller before use. Cells were transferred into stainless-steel bottles in an anacrobic chamber. The resuspending buffer contained $1 \mathrm{mM}$ $\mathrm{MgCl}_{2}$ and $1 \mu \mathrm{g}$ DNase I per my dry weight. The cell extract was centrifuged at $40000 \times g$ for 30 min in scaled slainless-stcel ubes, and aliquots frozen in liquid $\mathrm{N}_{2}$.

\section{Detemination of enzyme activities}

All enzyme activities were measured anoxically af room temperature. Gallate decarboxylase was assayed photometrically aftor Brune and Schink (1992) with $\mathrm{Mg}^{2+}$-free buffer. 1,2,3,5-Tetrahydroxybenzene: pyrogallol hydroxyltransferase was assayed by discontinuous IIPLC analysis according to Brupe and Schink (1990) with $1 \mathrm{mM}$ substrate concentrations. Phloroglucinol reductase was measured photometrically after Whittle et al. (1976). 3-Hydroxy-5oxohexanoate dehydrogenase was assayed photometrically according to Brune and Schink (1992). Acetyl-CoA synthase was measured with BV after Diekert and Thauer (1978). Hydrogenase was measured after Schink (1985).

The demethylating enzyme system was assayed as methyltransfer activity from the donors TMB or syringate to the acceptors sulfide or methanethiol at room temperature under $\mathrm{N}_{3}$ gas phase either photometrically or by discontimuous HPLC analysis of conversion of the methoxylated aromatic compounds Reaction mixtures usually contained $50 \mathrm{mM}$ potassium phosphate or $\mathrm{MOPS} / \mathrm{K}^{+}$ buffer, pH 7.2, $2 \mathrm{mM}$ titanium(III) plus $3 \mathrm{mM} \mathrm{NTA,} 2-10 \mathrm{mM}$ TMB or syringate (Na-salts), excess amoutits $(5 \mu$ moly of the volatıle methyl acceptors $\mathrm{Na}_{2} \mathrm{~S}$ or $\mathrm{CH}_{3} \mathrm{SNa}_{4}$ and $1-15 \mathrm{mg}$ proten $\mathrm{ml}{ }^{1}$ in a final wolume of $250 \mu 1$. The photumetric assay was performed in stoppared $5 \mathrm{~mm}$ light path cuvettes (770 $\mu 1$ volume) to lower extinction due to high protein concentrations, using a modified cuvette holder. The discontinuous HPLC assay was performed in stoppered Durham tubes ( $500 \mu \mathrm{l}$ volume) or larger glass vials.

\section{Corrinoid isolation and purification}

A cyanocorrmoid was extracted from cells of a 1 l culture according to Kengen et al. (1988) and purified by HPLC after Stupperich et al. $\{1986\}$

\section{Chemical analyses}

Aromatic compounds were analysed by $\mathrm{C}_{18}$ reversed phase HPLC as previously described (Brune and Schink 1990). Samples (100 $\mu$ ) were injected into $400 \mu \mathrm{l} 100 \mathrm{mM} \mathrm{H}_{3} \mathrm{PO}_{4}$ and frozen. Acclate was analysed by gas chromatography as previously described (Platen and Schink 1987). CO 2 was measured by injecting headspace samples $(300 \mu 1)$ into a gas chromatograph (Vega 6000 Carlo Erba. Milano, Italy) equipped with a hot wire detector (filament temperature $\left.280^{\circ} \mathrm{C}\right)$, a Carbosieve SII column $(100 / 120$ mesh, $2 \mathrm{~m} \times 2 \mathrm{~mm}$, Supelco, Bellefonte, Pa, USA) and an integrator. Conditions were: column, injector and detector temperatures $180^{\circ} \mathrm{C}$, He gas flow $50 \mathrm{ml} \mathrm{min}{ }^{-1}$. For quantification of dimethylsulfide, headspace samples ( 100 ul) were injected into a gas chromatograph (Vega 6000. Carlo Erba, Milano, Italy) equipped with a flame ionization detector, a Chromosorb 101 column (100/200 mesh, $1 \mathrm{~m} \times 2 \mathrm{~mm}$. Manville, Denver, Co., USA) and an integrator. Conditions were; column temperature $135^{\circ} \mathrm{C}$, injector and detector temperatures $180^{\circ} \mathrm{C}, \mathrm{N}_{2}$ gas flow $40 \mathrm{ml} \mathrm{min} \mathrm{m}^{-1}$. Standards were prepared by injecting liquid dimethylsulfide into bottles heated in a waterbath to $50^{\circ} \mathrm{C}$ boiling point of dimethylsulfide: $37^{\circ} \mathrm{C}$. A one-step dilution by transfer of gas into a second heated bottle with a syringe followed. Concentralions were calculated using solubility data (Dacey et al. 1984). Protein was dotermined according to Read and Northcote (1981) using ovalbumin as standard.

\section{Chemicals}

Titanium(III)-nitrilotriacetate stock solutions were prepared atter Moench and Zeikus (1983), with $100 \mathrm{mM} \mathrm{TiCl}$ in 150 to $400 \mathrm{mM}$ NTA. The $100 \mathrm{~m} \mathrm{M} \mathrm{Ti}{ }^{3+}, 150 \mathrm{mM} \mathrm{NTA}^{2-}$ solution, pH 7.0 , contained $570 \mathrm{mM} \mathrm{NaCl}$. Triacetic acid (3,5-dioxohexanoic acid) and 1,2,3,5-tetrahydroxybenzene were prepared as described in Brunc and Schink (1992) and Brune and Schink (1990), respectively.

All chemicals and grases were of the highest purity available and from standard commercial sources. 5-Hydroxyvanillate was purchased from Plaltz and Bawer (Waterbury, Conn, USA).

\section{Results}

\section{Growth}

Strain TMBS 4 grew in sulfide-free media reduced with ascorbate $(1 \mathrm{mM})$ or cysteine $(1 \mathrm{mM})$ with $\mathrm{TMB}$ or 
gallate as substrate. Growth in both media required addition of thiosulfate $(50 \mu \mathrm{M})$ as sulfur source. No growth was observed on the reducing agents alone.

Growth yields on gallate and TMB in ascorbatereduced medium were $8.2 \mathrm{~g} \mathrm{dry}$ mass mol gallate ${ }^{-1}$ and $22.2 \mathrm{~g}$ dry mass mol $\mathrm{TMB}^{-\mathbf{i}}$, respectively. Thus, the growth yield per methoxyl group fermented was $4.7 \mathrm{~g} \mathrm{dry}$ mass $\mathrm{mol}^{-1}$. The growth rate on gallate in this medium was $0.059 \mathrm{~h}^{-1}\left(t_{d}=12 \mathrm{~h}\right)$. Growth rates on TMB were lower and depended on the substrate concentration. At an initial substrate concentration of $4.3 \mathrm{mM}$ or $5.3 \mathrm{mM}$, growth rates were $0.023 \mathrm{~h}^{-1}\left(t_{d}=30 \mathrm{~h}\right)$ or $0.0195 \mathrm{~h}^{-1}$ $\left(t_{d}=35.5 \mathrm{~h}\right)$, respectively. In fed-batch culture with three subsequent additions of $\leq 2 \mathrm{mM}$ TMB during growth, a higher growth rate of $0.035 \mathrm{~h}^{-1}\left(t_{d}=20 \mathrm{~h}\right)$ was observed in cysteine-reduced medium.

\section{Enzymes of the phloroglucinol}

and the acetyl-CoA pathway

TMB degradation by cell extracts led to transient formation of syringate and 5-hydroxyvanillate, and syringate degradation to transient formation of 5hydroxyvanillate, suggesting sequential demethylation of TMB. Table 1 shows activities of enzymes of the phloroglucinol and the acetyl-CoA pathway. Gallate decarboxylase activity was not stimulated by addition of $\mathrm{MgCl}_{2}$ $(1-100 \mathrm{mM})$ nor did addition of EDTA $(1-2.5 \mathrm{mM})$ inhibit the enzyme. The activity of this enzyme was rather stable in $\mathrm{Mg}^{2+}$-free buffer at $4^{\circ} \mathrm{C}$, and decreased to $87 \%$ of the initial activity in $17 \mathrm{~h}$.

Table 1. Specifie aclivities of cnzymes of the phloroglucinol and the acetyl-CoA pathway

\begin{tabular}{|c|c|c|}
\hline \multirow[t]{2}{*}{ Enzyme } & \multicolumn{2}{|c|}{$\begin{array}{l}\text { Specific activity } \\
{\left[\text { numol min } \text { mg protein }^{-1}\right]} \\
\text { in extracts of cells grown on }\end{array}$} \\
\hline & TMB $^{:}$ & gallate $^{b}$ \\
\hline $\begin{array}{l}\text { Gallate decarboxylase } \\
1,2,3,5 \text {-Tetrahydroxybenzene: } \\
\text { pyrogallol hydroxyltransferase }\end{array}$ & $\begin{array}{l}120 \\
290\end{array}$ & $\begin{array}{l}\text { n.d. } \\
\text { n.d. }\end{array}$ \\
\hline $\begin{array}{l}\text { Phlaroglucinol reductase } \\
\text { (NADPH) }^{d} \\
\text { 3-Hydroxy-5-oxo-hexanoate } \\
\text { dehydrogenase (NADP }^{-} \text {) }^{\mathbf{a}}\end{array}$ & $\begin{array}{l}\text { n.d. } \\
4900\end{array}$ & $\begin{array}{l}3300 \\
\text { त.d. }\end{array}$ \\
\hline $\begin{array}{l}\text { Acetyl-CoA synthase (BV) } \\
\text { Hydrogenase (MV) }\end{array}$ & $\begin{array}{l}230 \\
120\end{array}$ & $\begin{array}{l}1.6 \\
1900^{\mathrm{i}}\end{array}$ \\
\hline
\end{tabular}

a Cells were grown on TMB, in vivo activity of TMB degradation was $35 \mathrm{nmol} \min ^{-1} \mathrm{mg}$ protein ${ }^{-1}$ (if $t_{d}=30 \mathrm{~h}$ ), except for acetylCoA synthase assay for which cells were grown on syringate

b In vivo activity of gallate degradation was $240 \mathrm{nmol} \mathrm{min}^{-1} \mathrm{mg}$ protein $^{-1}$

s not determined

d Activity with NADII was about $0.2 \%$ of that with NADPH as cosubstrate

- Activity with $\mathrm{NAD}^{+}$was $11 \%$ of that with $\mathrm{NADF}^{+}$as cosubstrate

${ }^{f}$ Measured with CTAB permcabilized colls

\section{Methyltransfer in cell suspensions}

Demethylation in cell suspensions required either one of the methyl acceptors $\mathrm{HS}^{-}$, $\mathrm{CO}$, or the $\mathrm{CO}$-precursor $\mathrm{CO}_{2}$ and was detected only with cells grown on methoxylated aromatic compounds. Demethylation activity increased proportionally with the concentration of either one of the methyl acceptors $\mathrm{Na}_{2} \mathrm{~S}$ or $\mathrm{CO}_{2}$ in the concentration range tested $(0-2 \mathrm{mM})$. The rate of TMB degradation

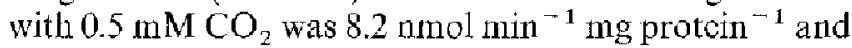
the rate of dimethylsulfide production from syringate with $0.5 \mathrm{mM} \mathrm{Na} 2 \mathrm{~S}$ was $6.2 \mathrm{nmol}^{\mathrm{min}^{-1} \mathrm{mg} \text { protein }}{ }^{-1}$. $\mathrm{CO}_{2}$-dependent demethylation did not recuire addition of external electron donors. Demethylation activity with

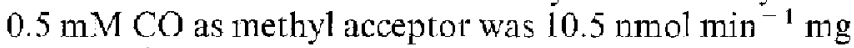
protein $^{-1}$. Syringate-grown cells demethylated also TMB and vice versa. Sulfide was used as a methyl acceptor by cells grown in medium without added sulfide. Cells of strain TMBS 4 lost the ability to use $\mathrm{CO}_{2}$ as methyl acceptor if they were not harvested under strictly anoxic conditions.

Cell suspensions using $\mathrm{CO}_{2}$ as methyl acceptor formed more than $80 \%$ of the amounts of acetate expected for TMB degradation (0.75 acetate per methoxyl group + 3 acetate per aromatic nucleus). Cells growing with TMB lormed $96 \%$ of the expected amount of acetate.

$\mathrm{CO}_{2}$-dependent demethylation of TMB in cell suspensions was inhibited by propyl iodide (Fig. 1). Light treatment of cell suspensions for 5 min revived the activity from $12 \%$ to $75 \%$ of non-inhibited activity and from $8 \%$ to $57 \%$ of non-inhibited activity at 50 and $100 \mu \mathrm{M}$ propyl iodide, respectively. Light had no effect on activity in controls without propyl jodide. Degradation of gallate was not affected by $500 \mu \mathrm{M}$ propyl iodide. BV-dependent CO oxidation in cell cxtracts decreased to $67 \%$ of uninhibited activity after addition of enough propyl iodide to saturate the reaction mixture (solubility of propyl iodide is ca. $18 \mathrm{mM}$ ). Obviously, the strong

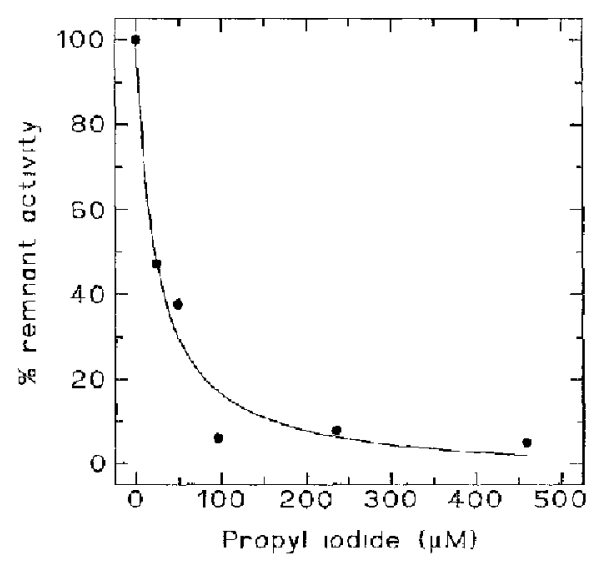

Fig. 1. Inhibition of $\mathrm{CO}_{2}$-dependent TMB demethylation in cell suspensions by propyl iodide. Cell suspensions (ca. $61 \mu \mathrm{g}$ protein $\mathrm{ml}^{-1}$ ) were supplied with $30 \mathrm{mM} \mathrm{NaHCO}$, and various amounts of propyl iodide were added from a freshly prepared $10 \mathrm{mM}$ stock solution $10 \mathrm{~min}$ before the reaction was started by addition of $2 \mathrm{mM}$ TMB (Na-salt). The activity of the control $(0 \mu \mathrm{M}$ propyl iodide) was $19 \mathrm{nmol} \mathrm{min}^{-1} \mathrm{mg}$ protein ${ }^{-1}$ 
inhibition of methyltransfer is an effect specific for this activity.

\section{Corrinoid isolation}

Cyanide extraction of cells grown on TMB in medium not supplemented with any corrinoid led to isolation of one kind of corrinoid. The purilied cyano-corrinoid had the same retention time $(16 \mathrm{~min})$ in HPLC at the conditions specified and the same absorption spectrum as authentic $\operatorname{Co} \alpha-[\alpha$-(5-hydroxybenzimidazolyl)]-Co $\beta$ cyanocobamide (factor III). Using cyanocobalamin as a standard, a corrinoid content of $750 \mathrm{nmol} \mathrm{g}^{\text {dry }}$ mass $^{-1}$ was estimated for strain TMBS 4.

\section{Methyltransfer in cell extracts}

Photometric assay of methyltransfer in cell extracts. TMB and syringate were demethylated to 5-hydroxyvanillate which forms a yellow complex with $\mathrm{Tj}^{3+}$. However, the downstream metabolites gallate and pyrogallol are also vicinal-diols and form yellow complexes with $\mathrm{Ti}^{3-}$ as well. TMB, syringate, and phloroglucinol do not complex $\mathrm{Ti}^{3+}$. Chemical alterations of the aromatic acids by $\mathrm{Ti}^{3+}$ were not observed.

The effect of $\mathrm{Ti}^{3+}$, NTA and $\mathrm{Mg}^{2+}$ at various concentrations on linearity and slope of extinctionconcentration curves (at different wavelengths from 370 to $470 \mathrm{~nm}$ ) was examined. Typical curves are shown in Figure 2. Linearity of the parabolic curves increased with i) increasing wavelength beyond that of the absorption maximum (about $375 \mathrm{~nm}$ ); ii) decreasing the proportion of NTA to $\mathrm{Ti}^{3+}$ in the $\mathrm{Ti}^{3-}$-NTA reagent; iii) decreasing the concentration of the $\mathrm{Ti}^{3}{ }^{1}$-NTA reagent and $\mathrm{iv}$ ) decreasing the $\mathrm{Mg}^{2+}$ concentration. Sensitivity of the assay for metabolite concentrations increased with decreasing wavelength and with decreasing proportion of NTA to $\mathrm{Ti}^{3+}$ in the $\mathrm{T}^{3+}-\mathrm{NTA}$ reagent, and was only slightly influenced by concentrations of the $\mathrm{Ti}^{3+}$-NTA reagent or of $\mathrm{Mg}^{2+}$. Extinction coefficients at $450 \mathrm{~nm}$

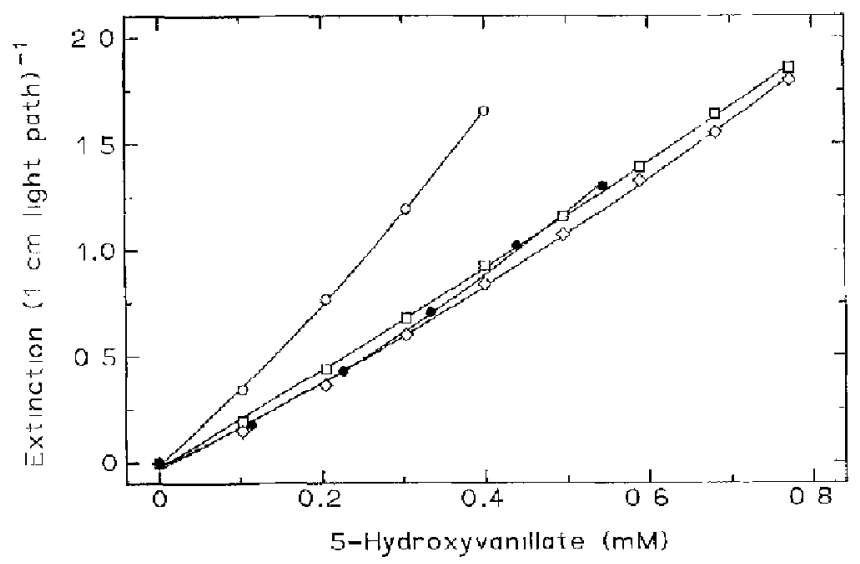

Fig. 2. Extinction of 5-hydroxyvanillate-Ti $\mathrm{i}^{3+}$-complexes under various conditions in $1 \mathrm{~cm}$ light path cuvettes. $2 \mathrm{mM} \mathrm{Ti}{ }^{3+}$ plus $3 \mathrm{mM}$ NTA (O), $2 \mathrm{mM} \mathrm{Ti}{ }^{3+}$ plus $8 \mathrm{mM}$ NTA (*), bolb measured at $400 \mathrm{~nm}$. $2 \mathrm{mM} \mathrm{Ti}^{3+}$ plus $3 \mathrm{mM}$ NTA (口), $10 \mathrm{mM} \mathrm{Ti}{ }^{3+}$ plis $15 \mathrm{mM}$ NTA (O), both neasured at $450 \mathrm{~nm}$ and at reagent concentrations $(2 \mathrm{mM} \mathrm{Ti}$ plus $3 \mathrm{mM}$ NT $\Lambda$ in $50 \mathrm{mM}$ MOPS buffer, $\mathrm{pH} 7.2$ ) assuring sufficient linearity of the response above $0.1 \mathrm{mM}$ aromatic acid (Fig. 2, 口) were: 5-IIydroxyvanillatc, $2.5 \mathrm{mM}^{-1} \mathrm{~cm}^{-1}$; gallate, $2.6 \mathrm{mM}^{-1} \mathrm{~cm}^{-1}$; and pyrogallol, $1.8 \mathrm{mM}^{-1}$ $\mathrm{cm}^{-1}$. The photometrically measured reaction eurves were linear with time after an initial short phase of substrate conversion if the cell extract was preactivated before reaction start in a reaction mixturc containing $\mathrm{Ti}^{3+}, \mathrm{A \Gamma P}$, and $\mathrm{Mg}^{2+}$ but no substrates.

Comparison of discontinuous and photonetric assay of methyltransfer activity. Light had no effect on activation or activity of the reaction mcasured photometrically. Reaction mixtures put into the light path for $10 \mathrm{~s} 5 \mathrm{~min}$ after reaction start and again after $10 \mathrm{~min}$ exhibited a reaction progress equal to that of the control which was permanently placed in the light path of the photometer. During photometric measurement of syringate demethylation, rcaction mixtures were simultaneously analysed by HPLC. They accumulated 5-hydroxyvanillate and pyrogallol, but no gallate, and usually no phloro-

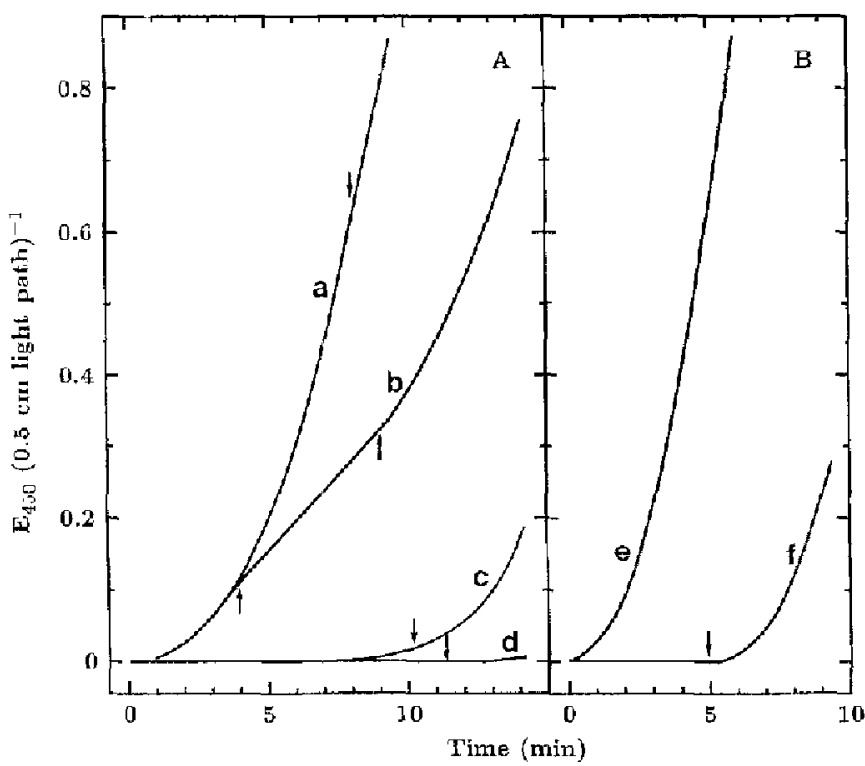

Fig. 3 A, B. Stimulation of activation of syringate demethylation activity by ATP A) and $\mathrm{Mg}^{2+}$ B) in cell extracts. Reaction progress was measured photometrically at $450 \mathrm{~nm}$ in $0.5 \mathrm{~cm}$ light path cuvettes. All assays contained $50 \mathrm{mM}$ MOPS buffer (pH 7.2), $10 \mathrm{mM}$ Na-syringate, $5 \mu \mathrm{mol} \mathrm{CH}_{3} \mathrm{SNa}, 2 \mathrm{mM} \mathrm{Ti}{ }^{3+}$ plus $3 \mathrm{mM} \mathrm{NTA}$ and $50 \mu$ cell extract containing $1 \mathrm{mM} \mathrm{MgCl}$ and 33 mg protein $\mathrm{ml}^{-1}$ in. a final voluthe of $250 \mu$ l. The reaction was started by addition of ecll extract, arrows indicate later additions. The maximal activities reached were similar $09 \%$ standard deviation) in all assays. The reaction mixtures and additions (atrowed) were as follows. Curve a: $2 \mathrm{mM} \mathrm{ATP}, 1 \mathrm{mM} \mathrm{MgCl} 2$ and $5 \mathrm{mM}$ glucose; $15 \mathrm{U}$ hexokinase (in $10 \mu$ ) was added during the phase of maximal activity. Curve $b$ : as for curve $a ; 15 U$ bexokinase were adeled carlier during the phase of activation; $13 \mathrm{mM}$ ATP was added later as an internal

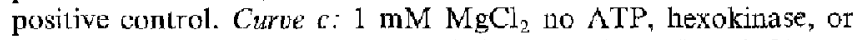
glucose; later $2 \mathrm{mM}$ ATP was added. Curve d: $1 \mathrm{mM} \mathrm{MgCl}_{3}$, no ATP, but $15 \mathrm{U}$ hexokinase and $5 \mathrm{mM}$ glucose; later $2 \mathrm{mM}$ ATP was added, even later $13 \mathrm{mM}$ ATP was added as a positive control This addition resulted in activation (not shown). Curve $e: 1 \mathrm{mM}$ $\mathrm{MgCl}_{2}$ and $10 \mathrm{mM} \mathrm{AlP}$. Curve $f: 10 \mathrm{mM}$ ATP, $10 \mathrm{mM}$ EDTA $\left(\mathrm{Na}_{2}\right.$ ) but no $\mathrm{MgCl}_{2}$; later $15 \mathrm{mM} \mathrm{MgCl}$ was added 
glucinol. The extenl of substrate conversion under conditions of different reaction velocities estimated photometrically was $0.90 \pm 0.11$ times lower than the extent determined by HPLC. The difference was due to pyrogallol production, which has a lower extinction coefficient than 5-hydroxyvanillate.

Reductive activation of methyltransfer. If the reaction was started by addition of cell cxtract, activity was observed only after a lag phase (Fig. 3), the extent of which depended on the age of the cell extract. In the absence of the reducing agent $\mathrm{Ti}^{3+}$, no activity was detected by HPLC. Activation in the presence of $\mathrm{Ti}^{3+}$ was greatly stimulated by the simultaneous presence of ATP and $\mathrm{Mg}^{2+}$ (Fig. 3). ADP stimulated the activation reaction as did ATP, but only in the absence of hexokinase and glucose. AMP had no elfect.

Dependence of the activation process and specific activity on protein concentration. Both activity and rate of activation, i.e. veloctiy and velocity of the increase of the concentration of active enzymes (measured as activity per volume) with time, increased not proportionally but in a more complex manner with increasing protcin concentration: Specific activity increased proportionally with protein concentration up to ca. $3 \mathrm{mg} \mathrm{m}^{-1}$ and reached a plateau of maximum specific activity of $20 \mathrm{nmol}$ $\mathrm{min}^{-1} \mathrm{mg}$ protein ${ }^{-1}$ at protein concentrations $\geq 10 \mathrm{mg}$ $\mathrm{ml}^{-1}$ (Fig. 4). The in vivo activity of $\mathrm{CO}_{2}$-dependent demethylation of ca. $35 \mathrm{nmol} \mathrm{min}{ }^{-1} \mathrm{mg}$ protein $^{-1}$ was of the same order of magnitude. The specific rate of activation, i.e. the maximal activity divided by lag phase length and protein concentration, depended strongly on protein concentration in a non-linear manner.

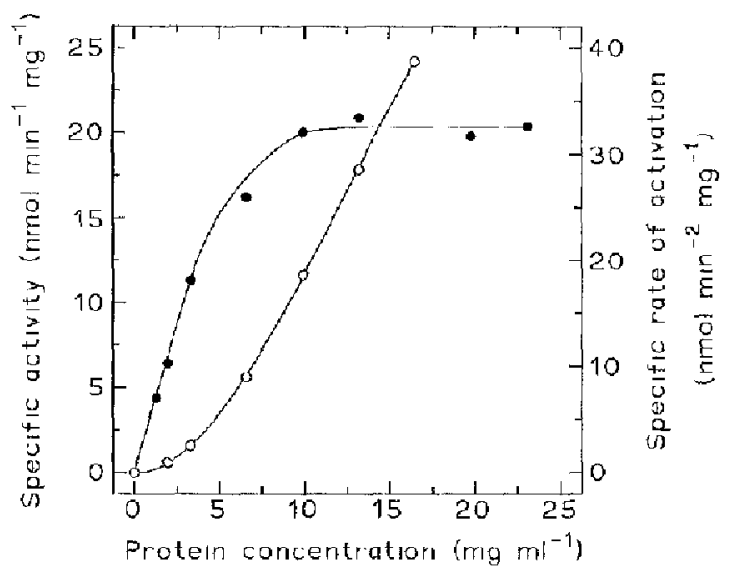

Fig. 4. Dependence on protein concentration of specifie activity (c) and specific rate of activation (c) of syringate demethylation by cell extracts. Reaction mixtures contained $50 \mathrm{mM}$ MOPS buffer (pII 7.2), $10 \mathrm{mM}$ Na-syringate, $5 \mu \mathrm{mol} \mathrm{Ch}_{3} \mathrm{SNa}_{2} 2 \mathrm{mM} \mathrm{Ti}{ }^{3-}$ plus $3 \mathrm{mMNTA}, 10 \mathrm{mM}$ ATP $\left(\mathrm{Na}_{2}\right)_{1} 1 \mathrm{mM} \mathrm{MgCl}$, and various amounts of cell extract ( $33 \mathrm{mg}$ protein $\mathrm{ml}^{-1}$ ) in a final volume of $250 \mu \mathrm{l}$. For measuring activation rates $(0)$ photometrically $(450 \mathrm{~nm}, 0.5 \mathrm{~cm}$ light path), the reaction was started by addition of cell extract. The specific activity was measured and divided by the protein concentration and the length of the lag phase of the reaction. Specific activity was measured by HPLC analysis of 5-hydroxyvanillate formation. The cell extract was preincubated in the reaction mixture (same composition as above) without syringate for $2 x$ the length of the lag phase determined photometrically under corresponfing conditions. Then the reaction was started by addition of syringate.
Further characteristics of methyltransfer. Cell extract $\left(100 \mu 1\right.$ with a protein concentration of $\left.25 \mathrm{mg} \mathrm{ml}^{-1}\right)$ treated with $10 \mathrm{U}$ of proteinase $\mathrm{K}$ for $20 \mathrm{~min}$ at room temperature was inactive. Heat-treatment $\left(5 \min 80^{\circ} \mathrm{C}\right)$ inactivated the coll extract as well. $\mathrm{O}_{2}$-treatment $(100 \mu \mathrm{l}$ cell extract was gently shaken with $5 \mathrm{ml}$ air for $15 \mathrm{~min}$ at room temperature followed by flushing with $\mathrm{N}_{2}$ ) caused only a slight loss (12\%) of activity. Activity could even be measured with cells harvested under air, but activation processes were rather slow and variable. Oxygen did not destroy activity irreversibly; whether oxygen inhibits reversibly cannot be tested with our system containing $\mathrm{Ti}^{3+}$ as reducing agent.

\section{Discussion}

In the present study, evidence was found for homoacetogenic metabolism of methyl groups derived from methoxylated aromatic compounds: i) $\mathrm{CO}_{2}$ was used as methy] acceptor for demethylation in growing and resting cells to form 0.75 acetate per methoxyl group, iil demethylation supported growth with a yield of $4.7 \mathrm{~g}$ dry mass per mol methoxyl group, and iii) acetyl-CoA synthase activity was present in cells grown with methoxylated aromatic compounds. The use of $\mathrm{CO}_{2}$ as methyl acceptor involves reduction of $\mathrm{CO}_{2}$ to $\mathrm{CO}$ and subsequent synthesis of acetyl-CoA by actyl-CoA synthase. Strain TMBS 4 did not require external electron donors for $\mathrm{CO}_{2}$ reduction but obtained those clectrons in partial oxidation of methyl groups to $\mathrm{CO}_{2}$. Gallate, the product of sequential demethylation of TMB, was degraded by the enzymes of the phloroglucinol pathway (Schink et al. 1992). Cell extracts of strain TMBS 4 catalysed (as far as tested) the same reactions as Pelobacter acidigallici extracts. However, gallate decarboxylase activity and stability were not enhanced by $\mathrm{Mg}^{2+}$, in contrast to the corresponding enzyme in Pelobacter acidigalli (Brune and Schink 1992). Hence, strain TMBS 4 combines the catabolic capabilities of homoacetogenic bacteria such as Acetobacterium woodii (Diekert 1992) and gallatefermenting anaerobes such as Pelobacier acidigallici. The pathway of TMB degradation by strain TMBS 4 is depicted in Fig. 5.

Wu et al. (1988) found demethylation in cell suspensions of Clostridium thermoaceticum to depend on $\mathrm{CO}$ if cells were grown with $\mathrm{CO}_{2}$ as methyl acceptor. $\mathrm{CO}_{2}$ did not support a higher demethylation rate than did $\mathrm{N}_{2}$, in contrast to our results. $\mathrm{CO}$ differs from $\mathrm{CO}_{2}$ in being not only a more direct methyl acceptor but also a low-potential reductant which can e.g. activate methyltransfer from $\mathrm{CH}_{3}-\mathrm{H}_{4}$ folate via corrinoid $/ \mathrm{Fe}-\mathrm{S}$ protein to acetyl-CoA synthase in Clostridium thermoaceticum (Ragsdale et al. 1987). We found a strictly anoxic cell harvest necessary for maintenance of the ability of cells of strain TMBS 4 to use $\mathrm{CO}_{2}$ as methyl acceptor.

Propyl iodide is a specific inhibitor of most corrinoiddependent methyltransferases (Taylor 1982; Kengen et al. 1988 and references therein). Light-reversible inhibition of methyltransfer by propyl iodide in strain TMBS 4 suggests involvoment of a corrinoid-dependent enzyme 


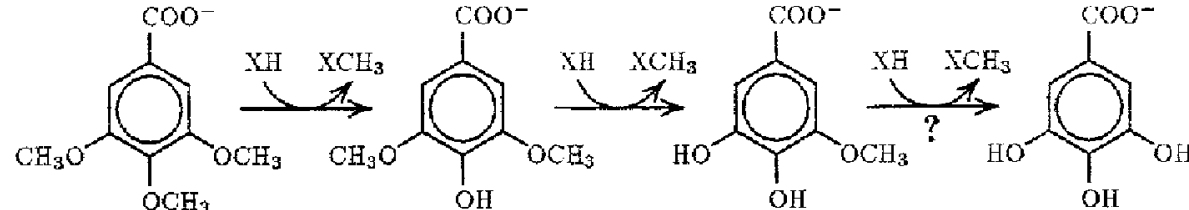

3,4,5-Trimethoxy- Syringate benzoate

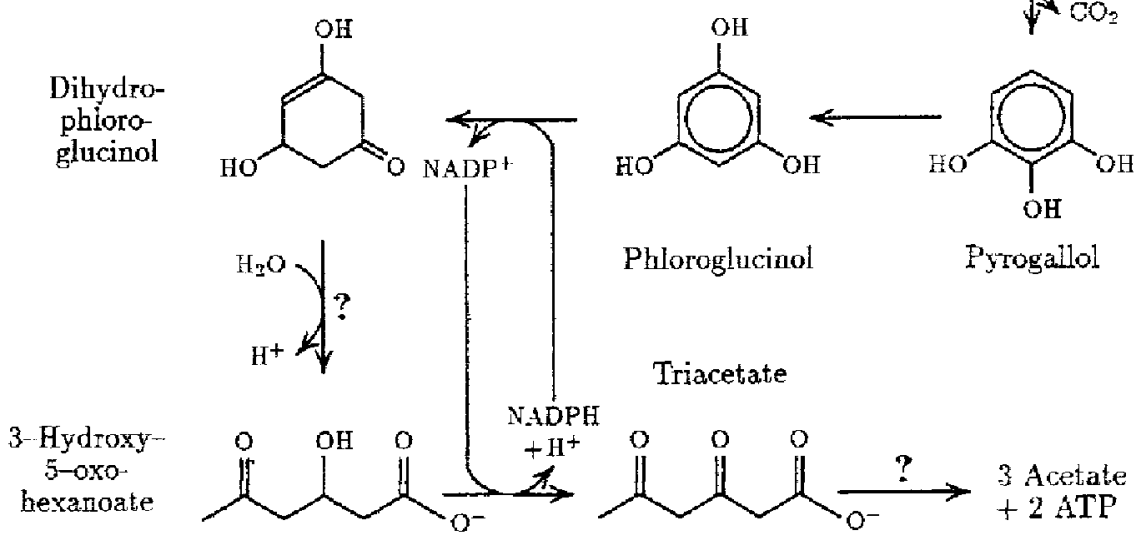

Fig. 5. Catabolism of 3,4,5-trimetlioxybenzoate by strain TMBS 4 : sequential demethylations followed by steps of the phloroglucinol pathway. Question marks indicate reactions which have not yet been tested in the methyltransfer sequence from the methoxylated aromatic compound to acetyl-CoA synthase. $\mathrm{H}_{4}$ folate served as a methyl acceptor in hydroferulate demethylation by cell cxtracts of Acetobacterium woodii (Berman and Frazer 1992). However, Dore and Bryant (1990) found that $\mathrm{H}_{4}$ folate inhibited acetate formation from vanillate by Syntrophococcus sucromutans. Both results can be explained assuming that $\mathrm{H}_{4}$ folate is not an intermediate in acetate formation from methoxyl groups, but acts as a sink for methyl groups diverting methyl flux away from acetyl-CoA synthase. In methanogens, the methyl group of methanol is transferred via a corrinoidcontaining and a further methyltransferase to coenzyme $M$ without involvement of pterins (van der Meijden et al. 1984a). Berman and Frazer (1992) found catalytic amounts $(20 \mu \mathrm{M})$ of cob(II)alamin to be ineffective as methyl acceptor. This can be expected since, in the absence of $\mathrm{CO}_{2}$ or $\mathrm{CO}$, stoichiometric amounts of a potential methyl acceptor would be required, and only cob(I)alamin, not cob(IT)alamin accepts methyl cations in a manner similar to $\mathrm{H}_{4}$ folate.

Methylation of sulfide by cells of strain TMBS 4 grown on methoxylated aromatic compounds might either be a specific but constitutive activity, or a side reaction of an enzyme of the methyltransfer sequence by which methyl groups are lost for the metabolism. The protein dependence, ATP stimulation of activation, and inactivation by heat and protease treatments clearly demonstrate sulfide methylation to be an enzymatic reaction. Chemical thiol alkylation by alkylcobalamins could be a model for the reaction mechanism. The mechanism of this methylation is known to be a nucleophilic attack of a thiolate anion on the alkyl carbon (Hogenkamp et al. 1985, 1987).

We developed a photomctric assay to measure demethylation. This assay offers the advantage of continuous measurement of the non-linear reaction progress curves with good time resolution, which is particularly valuable for measuring the length of lag phases and rates of activation. Also, it allows convenient and fast activity tests of fractions in enzyme chromatography and in screening for effects of various additions on enzyme activity. However, there are also disadvantages of this photometric assay: $\mathrm{Ti}^{3+}$ acts both as reducing agent and as reaction partner in colour formation. Calibration curves were more or less obviously non-linear, and the choice of reagent concentrations is restricted by the requirement for almost linear curves. $\mathrm{Ti}^{3+}$, which has to be kept soluble by some complexing agent, is required for colour formation. This complexing agent lowers the concentration of free $\mathrm{Mg}^{2}-$ (and other polyvalent cations) and hence the concentration of Mg-ATP in the assay is not well defined. The first product of demethylation must accumulate and complex $\mathrm{Ti}^{3}{ }^{3}$. This will be no problem in work with other homoacetogenic bacteria which do not metabolize the demethylated substrate further.

Significantly high demethylation activities in cell extracts were first dernonstrated by Berman and Frazer (1992). We obtained reproducible and high activities of methyltransfer only if bigh protein concentrations, ATP, and a low-potential reductant were present. Berman and Frazer (1992) also used high protein concentration, ATP, and usually cmployed reductants such as pyruvate (potential reductant in the presence of CoA and cell extract), dithioerythritol, cysteine, and a gas phase containing $3 \%$ $\mathrm{H}_{2}$. Studies of corrinoid-dependent methyltransler reactions in catabolism demonstrate in general involvement of ATP and low-potential reductants $\left(\mathrm{H}_{2}\right.$, reduced ferredoxin, $\mathrm{CO}, \mathrm{Ti}^{3-}$, in reductive activation (van der Meijden et al. 1984 a, b; Ragsdale et al. 1987; Kengen et al. 1988; van de Wijngaard et al. 1991).

The activity of methyltransfer by extracts of strain 
TMBS 4 was not proportional to protcin concentration but showed a quadratic dependence up to $3 \mathrm{mg} \mathrm{ml}^{-1}$, i. c., the specific activity was proportional to protein concentration. This finding renders statements on specific activities of this enzyme reaction questionablc. Berman and Frazer (1992) also found a quadratic dependence of activity in Acerobacterium woodii on protein concentration, although not stating this explicitly: a parabola of the form $y=a x^{2}$ fits well to their data except for the highest protein concentration used. If the reaction rate is limited by the rate of interaction of two components of the cell extract, e.g. two enzymes, two subunits of one dissociable enzyme, or one enzyme and one coenzyme, the reaction rate would be a quadratic function of cell extract concentration. Application of high protein concentrations is a common feature of reports on demethylation or other methyltransfer systems (Doré and Bryant 1990; Kengen et al. 1990; van de Wijngard et al. 1991; Berman and Frazer 1992).

The situation is further complicated by the complex dependence of the reductive activation process on protein concentration. This indicates involvement of proteinprotein interaction in the activation.

We demonstrated that ATP was not necessary for the demethylation reaction itself once the enzymc system was activated: Addition of bexokinase to remove ATP from the reaction mixture (glucose was present) stopped further activation and the level of activity already reached was maintained. Addition of hexokinase to the completely activated system had no effect on activity. If hexokinase and glucose were not present, a slow activation occurred without addition of ATP, especially if fresh cell extract was used. This effect might be due to low levels of remnant ATP in the concentrated cell extract. The stimulation by ADP probably was due to conversion to ATP by nucleoside diphosphate kinasc in the cell extract, because hexokinase and glucose prevented the ADP effect. However, nucleoside diphosphate kinase activity was not tested.

Future work in our laboratory will concentrate on elucidation of activity and activation of the methyltransferase system.

Acknowledgemerts: We are grateful to Dr. E. Stupperich (University of $\mathrm{Vlm}$, Germany) for corrinoid identification, to Dr. A. Brune for many helpful discussions and for supplying triacetate and tetrahydroxybenzenc, and to Dr. P. H. Janssen for critically reading the manuscript.

\section{References}

Axelrod J (1956) The enzymic cleavage of aromatic ethers. Biochem J $63: 634-639$

Bache R, Pfennig N (1981) Selective isolation of Acetobacterium woodif on methoxylated aromatic acids and determination of growth yields. Arch Microbiol 130: 255-261

Bak F, Finster K, RothfuB F (1992) Formation of dimethylsulfide and methanethiol from methoxylated aromatic compounds and inotgauic sulfide by newly isolated anaerobic bacteria. Arch Microbiol 157: $529-534$
Berman MH, Fraces AC (1992) Importance of tetrahydrofolate and ATP in the anaerobic $\mathrm{O}$-demethylation reaction for phenylmethylethers. Appl Environ Microbiol 58: 925-931

Bernhardt $F \cdot H$, Staudinger $H$, Ulrich $V(1970)$ Eigenschaften einer p-Anisat-O-Demethylase im zellfreien Extrakt von Psetrdomonas species. Hoppe-Seyler's Z Physiol Chem 351: 467-478

Brune A, Schink B (1990) Pyrogallol-to-pliloroglucinol conversion and other hydroxyl-1ransfer rcactions catalyzed by cell extracts of Pelobacter acidigallici. I Racteriol 172: 1070-1076

Brune A, Schink B (1992) Phloroglueinol palhway in the strictly anacrobic Pelobacter acdigalici: fermentation of trihydroxybenzenes to acetate via triacetic acid. Arch Microbiol 157; $417-424$

Dacey JWH, Wakeham SG, Huwes BL (1984) Henry's law constants for dimethylsulfide in freshwater and seawatcr. Geophys Res Lett 11: $991-994$

DeWeerd KA, Saxena A. Nagle DP Jr. Suflita JM (1988) Metabolism of the ${ }^{18} \mathrm{O}$-methory substituent of 3 -methoxybenzoic acid and other unlabeled methoxybenzoic acids by anaerobic bacteria. Appl Environ Microbiol 54: 1237-1242

Diekert $\mathrm{G}$ (1992) The acetogenic bacteria. In: Balows A, Trüper HG, Dworkin M, Harder W, Schleifer $\mathrm{K}-\mathrm{H}$ (eds) The Prokaryotes, 2nd edn. Springer, Berlin Heidelberg New York, pp $517-533$

Diekert $\mathrm{G}$, Thauer RK (1978) Carbon monoxide oxidation by Clostridian thermouceticum and Clostidiun formicoaceticum. J Bacteriol 136: 597-606

Doré I, Bryant MP (1990) Metabolism of one-carbon compounds by the ruminal acetogen Syntrophococcus sucromutans. Appl Environ Microbiol 56: 984-989

Finster K, King GM, Bak F (1990) Formation of methylmercaptan and dimethylsulfide from methoxylated aromatic compounds in anoxic marine and fresh water sediments. FFMS Microbiol Ecol 74: 295-302

Finster $K$, Tanimoto $Y$, Bak $F$ (1992) Fermentation of methanethiol and dimethylsulfide by a newly isolated methanogenic bacterium. Arch Micrabiol 157: 425-430

Healy JB Jr. Young LY (1979) Anaerobic biodegradation of eleven aromatic compounds to methane. Appl Environ Microbiol 38: 84-89

Hogenkamp HPC. Bratt GT, Sun SZ (1985) Methyi transîer from methylcobalanin to thiols. A reinvestigation. Biochemistry 24 : $6428-6432$

Hogenkamp HPC, Bratt GT. Kotchevar AT (1987) Reaction of alkylcobalamins with thiols. Biochemistry 26: 4723-4727

Kengen SWM, Mosterd JJ, Nelissen RL.H, Keltjens JT, Drift C van der, Vogels GD (1988) Reductive activation of the methyttetrahydromethanopterin: coenzyme $M$ methyltransferase from Methanabacterium thermoautotrophican strain $\Delta \mathrm{H}$. Arch Mircobiol 150: 405-412

Kengen SWM, Daas PJH, Keltjens JT, Drift C van der, Vogels GD (1990) Stimulation of the tetrahydromethanopterin: coenzyme $M$ methyltransferase reaction in cell-free extracts of Methanobacterium thermoautotrophicum by the beterodisulfide of coenzyme $\mathrm{M}$ and 7 -mercaptoheptanoylthreonine phosphate. Arch Microbiol 154: 156-161

Moench TT, Leikus JG (1983) An improved preparation method for a titanium(III) media reductant. J Microbiol Methods 1: $199-202$

Platen H, Schink B (1987) Methanogenic degradation of acetone by an entichment culture. Arch Microbiol 149: 136-141

Ragsdale SW, Lindahl PA, Münck E (1987) Mössbaner, EPR, and optical studies of the corrinoid/iron-sulfur ptotein involved in the synthesis of acetyl. coenzyme A by Clostridium thermoaceticum. I Biol Chem 262: 14289-14297

Read SM, Northcote DH (1981) Minimization of variation in the response to different proteins of the coomassie blue $G$ dyebinding assay for protein. Amal Biochem 116:53-64

Schink B (1985) Fermentatiotn of acetylene by an obligate anacrobe, Pelobacter acetylenicus sp. nov. Arch Microbol 142: 295-301 
Schink B, Brune A, Schnell S (1992) Anaerobic degradation of aromatic compounds. In: Winkelmann $G$ (ed) Microbial degradation of natural products. Verlag Chemie, Weinheim, pp $219-242$

Stupperich E, Steiner I. Rühlemann M (1986) Isolation and analysis of bacterial cobamides by high-performance liquid chromatography. Anal Biochem 155: 365-370

Taylor RT (1982) $B_{12}$-dependent metlionine biosynthesis. In:

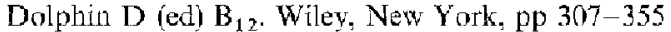

Wijngaard WMH van de, Lugtigheid RL, Drift C van der (1991) Reductive activation of the corrinoid-containing enzyme involved in methyl group transfer between methyl-tetrahydromethanoptersn and coenzyme $\mathrm{M}$ in Methanosarcina barkeri. Antonie van Leeuwenhoek 60: 1--6

Meijden P van der, Brommelstroet BW te, Poirot CM. Drift C van der, Vogels GD (1984a) Purification and properties of melhanol: 5-hydroxybenzimidazolylcobamide methyltransferase from Methonosarcina burkert. I Bacteriol 160:629-635

Meijden $P$ van der, Lest $C$ van der, Drift $C$ van der. Yogels
GD (1984b) Reductive activation of methanol: 5-hydroxybenzimidazolylcobamide methyltransferase of Methanosarcina batkeri. Biochem Biophys Res Commun 118: 760-766

Whittle PJ, Lunt DO, Evans WC (1976) Anaerobic photometabolism of aromatic compounds by Rhodopseudomonas $\mathrm{sp}$ Brochem Soc Trans 4: 490491

Widdel F, Pfennig N (1981) Studies on dissimilatory sulfatereducing bacteria that decompose fatty acids. I. Isolation of new sulfate-roducing backeria enriched with acelate from saline environments. Description of Desulfobacter pastgatet gen. nov., sp. now. Arch Misrobiol 129:395-400

Widdel F, Kohring GW, Mayer F (1983) Studies on dissimilatary sulfate-reducing bacteria that decompose fatty acids. III. Characterization of the filamentous gliding Desulfonema limicola gen. nov. sp. nov, and Desulfonema magnum sp. nov. Arch Microbiol 134: 286-294

Wu Z, Daniel SL, Drake H (1988) Characterization of a COdependent $O$-demethylating enzyme system fiom the acetogen Chostridium thermoaceticum. I Bacteriol 170: 5747-5750 